\title{
ТЕОРЕТИЧНІ АСПЕКТ СИСТЕМИ БАНКІВСЬКОГО МЕНЕДЖМЕНТУ
}

\author{
Луцький національний технічний університет
}

\begin{abstract}
У статті на основі проведеного аналітичного дослідження з використанням методу синтезу сформовано теоретичні підходи до трактування поняття «банківський менеджмент» 3 точки зору дискусійних аспектів в частині дефініції, принципів та функцій.

За результатами проведеного дослідження теоретичних аспектів банківського менеджменту систематизовано наукові підходи до формування поняття «банківський менеджмент», зокрема: системний, маркетинговий, ситуаційний, функціональний, процесний, нормативний та адміністративний підходи. Визначено елементи банківського менеджменту з точки зору об` єкта та суб єкта.

Обгрунтовано, що ефективність реалізації банківського менеджменту залежить від комплексності сформованих принципів та реалізації загальних функцій банківського менеджменту, що сприятиме швидкому досягненню цілей з мінімальними затратами усіх ресурсів. Відповідно у статті виокремлено зальні функції банківського менеджменту та сформовано принципи реалізації механізму банківського менеджменту.

Ключові слова: банківський менеджмент, приниипи банківського менеджменту, наукові підходи, функиії управління банком.
\end{abstract}

\section{THEORETICAL ASPECTS OF THE BANK MANAGEMENT SYSTEM}

\author{
Lutsk National Technical University
}

The article, based on an analytical study using the method of synthesis, formed theoretical approaches to the interpretation of the concept of «banking management» in terms of discussion aspects in terms of definition, principles and functions.

According to the results of the research of theoretical aspects of bank management, scientific approaches to the formation of the concept of «banking management» are systematized, in particular: system, marketing, situational, functional, process, normative and administrative approaches. Elements of bank management from the point of view of object and subject are defined.

It is substantiated that the effectiveness of the implementation of banking management depends on the complexity of the established principles and the implementation of the general functions of banking management, which will contribute to the rapid achievement of goals with minimal costs of all resources. Accordingly, the article highlights the hall functions of bank management and forms the principles of implementation of the banking management mechanism.

Key words: bank management, principles of bank management, scientific approaches, functions of bank management.

Постановка проблеми у загальному вигляді і її з важливими науковими та практичними завданнями. Важливою складовою успіху діяльності відкритої соціально-економічної системи, у тому числі банків є грамотна система управління. Сучасний стан банківської системи з одного боку є відображенням загального стану економіки, але водночас $\epsilon$ наслідком некваліфікованого управління. Питання ефективного менеджменту у банківській сфері в Україні є найменш розробленими. Тому керівникам банківських установ доводиться організовувати діяльність у банку, базуючись лише на індивідуальному сприйнятті дійсності, а не на системному підході до управління банком. Відповідно наслідком нехтування формулювання чіткої концепції розвитку є відсутність планування діяльності взагалі, або недотримання логічного взаємозв’язку між послідовними етапами процесу прийняття управлінських рішень - 
аналізом, плануванням, організацією, контролем та регулюванням. Отже, в сучасних умовах формується об'єктивна потреба в поглиблених наукових дослідженнях системного управління діяльністю банків, у теоретичному осмисленні основних понять, розробці методів організації та управління банківською діяльністю, які відповідають сучасним реаліям розвитку банківської системи. Відповідно у зв'язку з посиленням впливу фінансових складових економічних відносин, загостренням конкуренції на ринку банківських послуг, зростає значення банківського менеджменту у сучасних умовах.

Аналіз останніх досліджень та публікацій. Дослідженням теоретичних питань та практичного застосування менеджменту загалом та в банках займалась значна кількість вітчизняних, а також закордонних вчених та науковців. Зокрема, дослідженням сутності поняття менеджмент присвячені праці видатних вчених: П. Друкера, М. Фоллет, Ф. Тейлора, Е. Мейо, Анрі Файоля та ін. Серед вітчизняних та російських науковців заслуговує на увагу внесок у розвиток науки про управління банками I. Комарницького, А. Попова, Л. Євенка, Л. Нечаюка, О. Нестулі та ін.

Цілі статті. Відповідно ціллю статті є теоретичне обгрунтування, систематизація наукових підходів та виокремлення ключових принципів системи банківського менеджменту.

Виклад основного матеріалу дослідження 3 повним обгрунтуванням отриманих наукових результатів. Загалом, під менеджментом розуміємо систему методів, принципів, інструментів, форм та прийомів управління підприємством в умовах ринкової економіки, що спрямовані на ефективне використання усіх наявних ресурсів підприємства для одержання найвищих результатів діяльності. Проте існують розбіжності у розумінні сутності поняття менеджменту банків, формуванні принципів, методів та інструментів практичного використання, оскільки банківський менеджмент $\epsilon$ різновидом загального менеджменту, який виконує специфічні функції, вимагає застосування спеціальних інструментів та методів.

Водночас варто зазначити, що банківський менеджменту має свою специфіку, що обгрунтовується особливостями організації системи управління банком та діяльності банківської установи загалом. Основною відмінністю між підприємством та банком є те, що основною діяльністю бізнесу $є$ виробництво товарів, надання послуг або здійснення торгівлі, а основною діяльністю банківської установи $є$ концентрація на фінансових ринках. Тобто в бізнесі фінансові операції є необхідними для ефективного здійснення основної виробничої діяльності, а для банків основною діяльністю є фінансові операції. Тому банківський менеджмент часто ототожнюють 3 поняттям фінансового банківського менеджменту. Водночас особливостями банківського менеджменту є об'єктивна необхідність управління залученими фінансовими ресурсами; · жорстке державне регулювання діяльності; широкий перелік операцій, що пов язано з функціонуванням банків на одному або більше фінансових ринках; · пряма залежність від стану національної та світової економіки, а не лише від кон'юнктури.

Систематизація існуючих визначень менеджменту банку подано у таблиці 1.

Таблиця 1. Визначення змісту дефініції «менеджмент банку»

\begin{tabular}{|l|l|}
\hline \multicolumn{1}{|c|}{ Автор } & \multicolumn{1}{|c|}{ Визначення поняття } \\
\hline \multicolumn{1}{|c|}{$\begin{array}{l}\text { В. Краснова та } \\
\text { Б. Жнякіна }\end{array}$} & $\begin{array}{l}\text { «фінансовий банківський менеджмент - це система принципів, засобів та форм } \\
\text { організації грошових відносин підприємства, спрямованих на управління його } \\
\text { фінансово-господарською діяльністю, в яку входять: розроблення та реалізація } \\
\text { фінансової політики, інформаційне забезпечення (складання і аналізування фінансової } \\
\end{array}$ \\
& $\begin{array}{l}\text { звітності), оцінювання інвестиційних та інноваційних проектів і формування } \\
\text { «портфеля» інвестицій, а також поточне фінансове планування та контроль» [1] }\end{array}$ \\
\hline
\end{tabular}


Продовження табл. 1 .

\begin{tabular}{|c|c|}
\hline 1 & 2 \\
\hline Є.Г. Рясних & $\begin{array}{l}\text { «фінансовий менеджмент визначається як підсистема загального управління } \\
\text { господарсько-комерційною діяльністю, яка охоплює сукупність принципів, } \\
\text { методів і форм організації управління усіма аспектами його фінансової діяльності } \\
\text { i спрямована на реалізацію стратегічних і тактичних цілей» [2] }\end{array}$ \\
\hline Ж.Довгань & $\begin{array}{l}\text { «банківський менеджмент - це управління всіма процесами, які характеризують } \\
\text { діяльність банку, його відносинами (фінансовими, економічними, трудовим, } \\
\text { техніко-технологічними, організаційними, правовими, соціальними та ін.), які } \\
\text { пов'язані із стратегічним і тактичним плануванням, аналізом, регулюванням та } \\
\text { контролем діяльності банку, управлінням фінансами, маркетинговою діяльністю, } \\
\text { персоналом. Зміст цього поняття охоплює сукупність принципів, методів і } \\
\text { технологій управління банком } 3 \text { метою збереження конкурентних переваг, } \\
\text { підвищення прибутковості банку за умови дотримання надійності та ліквідності» } \\
\text { [3] }\end{array}$ \\
\hline О. Криклій & $\begin{array}{l}\text { «Банківський менеджмент - наука про системи управління всіма аспектами } \\
\text { діяльності банку для досягнення його стратегічних цілей i забезпечення } \\
\text { фінансової стійкості» [4] }\end{array}$ \\
\hline $\begin{array}{l}\text { О. Кириченко, I. } \\
\text { Гіленко }\end{array}$ & $\begin{array}{l}\text { «банківський менеджмент - це управління банком в умовах ринку, що означає: } \\
\text { орієнтацію банку на попит і потреби ринку, на запити клієнтів й організацію } \\
\text { таких банківських продуктів і послуг, які користуються попитом і можуть дати } \\
\text { банкові запланований прибуток; •постійне прагнення до підвищення } \\
\text { ефективності банківської діяльності } 3 \text { метою зменшення витрат і одержання } \\
\text { оптимальних результатів коригування цілей, завдань і програм банку залежно від } \\
\text { кон'юнктури ринку; необхідність використання сучасної інформаційної бази } \\
\text { (комп'ютерних мереж та зв'язків } 3 \text { валютною і фондовою біржами, іншими } \\
\text { кредитно-фінансовими інститутами) з метою здійснення багатоваріантних } \\
\text { розрахунків для прийнятя обгрунтованих і оптимальних рішень; раціональний } \\
\text { добір персоналу і його ефективне використання» [5] }\end{array}$ \\
\hline $\begin{array}{l}\text { Сокиринська І.Г., } \\
\text { Журавльова Т.О. }\end{array}$ & $\begin{array}{l}\text { «Банківський менеджмент - це наука про ефективні системи організації та } \\
\text { управління всіма процесами та відносинами, які характеризують діяльність } \\
\text { банку. Під процесами та відносинами розуміють всю сукупність } \\
\text { фінансових,економічних, організаційних і соціальних сфер банківської } \\
\text { діяльності» [6] }\end{array}$ \\
\hline
\end{tabular}

Примітка. Сформовано автором на основі джерел [1-6]

Отже, систематизація визначень сутності поняття банківський менеджмент дає можливість виокремити декілька підходів до розуміння цієї дефініції, зміст яких представлено на рисунку 1. Зокрема, виділяються: системний, маркетинговий, ситуаційний, функціональний, процесний, нормативний та адміністративний підходи.

Базуючись на адміністративному підході до розуміння сутності поняття менеджмент у банку та враховуючи напрацювання вчених щодо існуючих визначень вважаємо, що менеджмент у банку - сукупність принципів, засобів, форм та методів управління, які характеризують діяльність банку, спрямованих на оптимальне та ефективне використання усіх наявних ресурсів (фінансових, економічних, трудових, техніко-технологічних, організаційних, правових, соціальних та ін.).

У сучасній наукові літературі менеджмент банку поділяють на фінансовий та організаційний.

Організаційний банківський менеджмент стосується проблем організації, управління колективом та мотивації, створення організаційних структур та систем забезпечення діяльності банку, контролю та безпеки.

Фінансовий менеджмент у банку - система менеджменту, яка охоплює питання, пов'язані з фінансовими ринками, ліквідністю банку, фінансовими ризиками, ефективністю та прибутковістю використання окремих видів банківських операцій. 


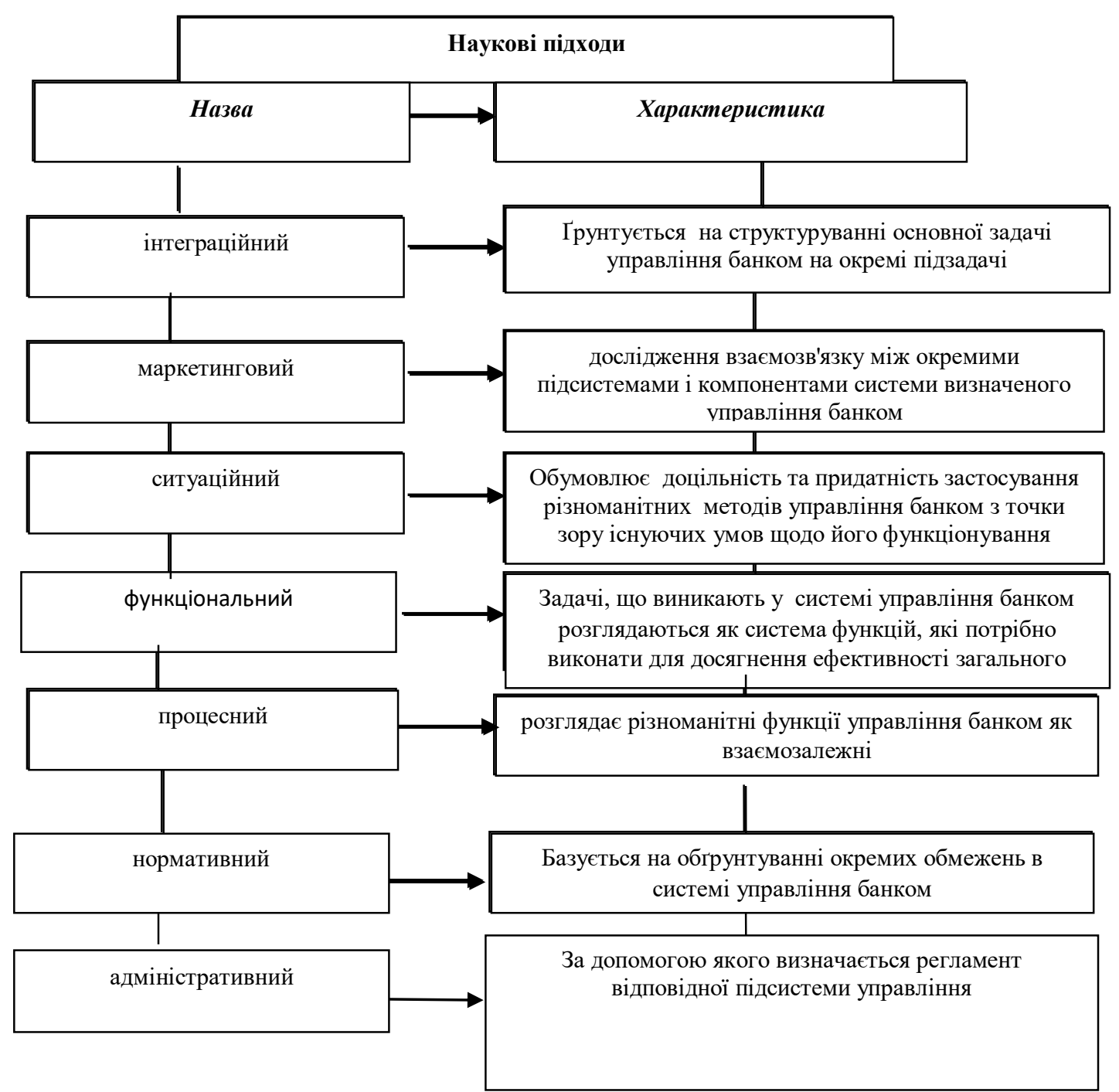

Рис.1. Підходи до розуміння сутності поняття менеджмент у банку та їх зміст Примітка. Сформовано автором

Банківський менеджмент базується на конкретних принципах і спрямований на виконання загальних функцій через використання специфічного інструментарію для досягнення цілей управління. Тому менеджмент банку характеризується принципами, які є спільними для всіх сфер діяльності. До основних складових системи менеджменту банку, можна віднести: суб'єкт і об'єкт, методи, принципи, інструменти та функції, тобто ефективна реалізація загальних та спеціальних функцій банківського менеджменту базується на певних принципах з використанням методів та інструментарію. Зупинимось детально на цих елементах.

Об'єктом менеджменту банку є організація системи контролю, планування банківської діяльності, системи безпеки банку, управління кадровим потенціалом, управління інформаційними технологіям, тобто усі процеси та аспекти в сфері організаційного банківського менеджменту у взаємозв'язку з політико-правовим та соціально-економічним середовищем. Суб'єктом банківського менеджменту є ланка системи управління, що здійснює безпосередній вплив на інші елементи системи управління, тобто відповідальна особа або група осіб, які наділені правом прийняття управлінських рішень і несуть відповідальність за ефективність здійснюваного процесу управління банком. До суб'єктів банківського менеджменту відносяться члени Ради директорів банку; члени Правління банку; керівництво, тобто персонал який здйснює 
управлінський вплив; менеджери, які безпосередньо здійснюють процес управління, тобто менеджмент (керівний склад) банку. Досягнення цілей банківського менеджменту залежить від якості сформованих та побудованих принципів як певних норм та основоположних засад системи управління банком. Водночас банківський менеджмент як наука та специфічний вид менеджменту базується на загальних принципах менеджменту, так і має специфічні принципи побудови. Систематизація загальних принципів банківського менеджменту подана на рисунку 2.

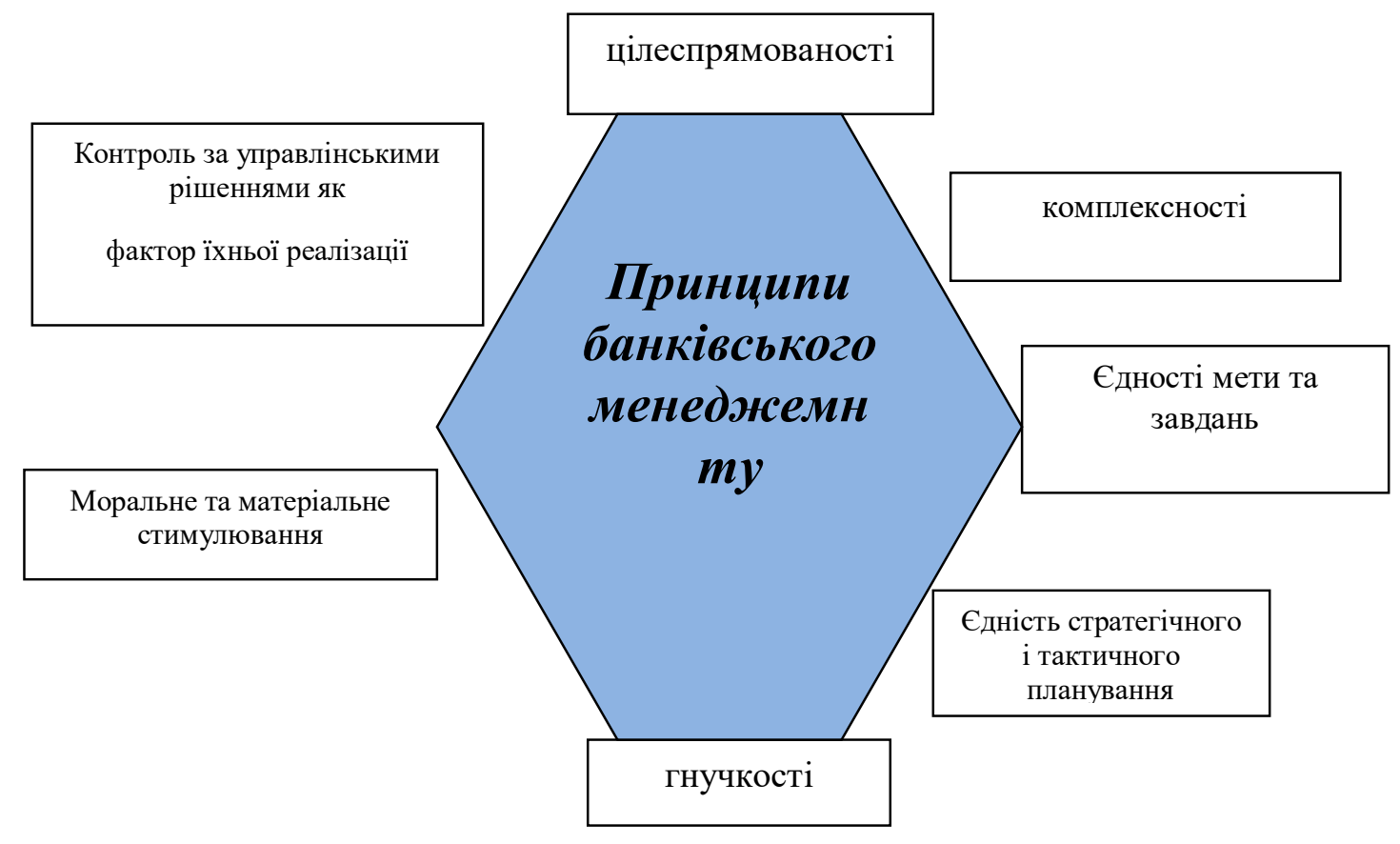

Рис. 2 Загальні принципи банківського менеджменту

Примітка. Сформовано автором на основі джерела [6] зокрема:

Водночас банківський менеджмент базується на специфічних принципах,

- поєднання принципів централізації і децентралізації в управлінні

- облік макроекономічних факторів та кон'юнктури фінансового ринку;

- орієнтація діяльності на ринковий попит, послуги кредитних організацій;

- оптимізація прибутковості і ризиків банківських операцій та ін.

Реалізація банківського менеджменту з використанням основних та специфічних принципів підвищуватиме ефективність управління банком, оскільки лише комплексне ï застосування спрятиме швидкому досягненню цілей з мінімальними затратами усіх ресурсів.

Механізм управління банком визначається як:

$$
\text { МЕХуб = f(Стру, КУ, ФУ, Ф та МУ })
$$

відповідно під Стру розуміються стратегічні цілі та стратегія банку;

КУ - критерії досягнення цілей банківського управління;

ФУ - фактори, на які розповсюджується управлінський вплив для забезпечення підтримання критеріїв управління на визначеному рівні (внутрішні фактори);

Ф та МУ - функції та методи управління банком.

Тому вважаємо, що ефективність управління банком залежить у значній мірі від функцій, під якими розуміємо відокремлені напрямки діяльності, що забезпечують ефективну та оптимальну реалізацію цілей управління.

Процес організаційного банківського менеджменту передбачає виконання загальних функцій: планування, організації, мотивації, контролю (рис. 3). 


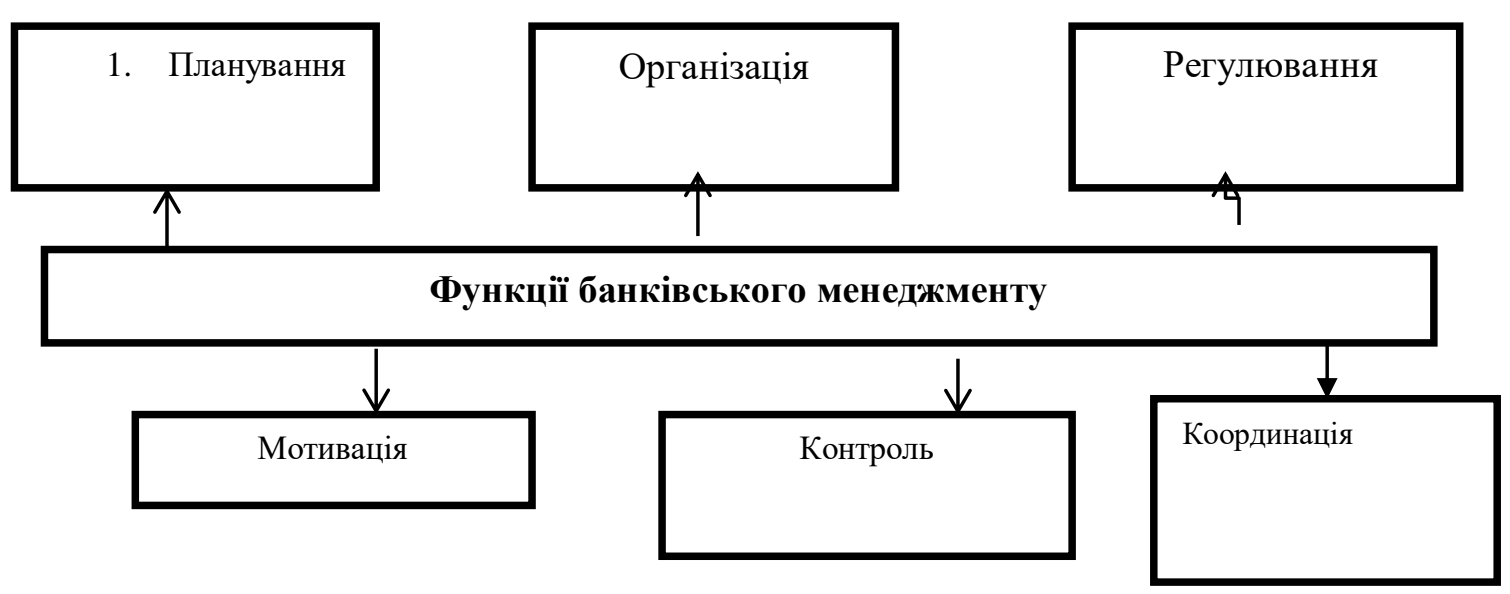

Рис. 3 Функції банківського менеджменту

Примітка. Сформовано автором на основі джерела [4]

Планування - основна ланка процесу управління, яка $\epsilon$ базовою функцією банківського менеджменту. Це один із засобів досягнення конкретної мети, тобто планування розглядається як процес формування цілей банку (стратегічних, тактичних, оперативних) на перспективу та пошук шляхів досягнення конкретно визначених цілей.

Для досягнення запланованих результатів та швидкого досягнення цілей діяльності банку необхідним є налагоджена організація взаємодії діяльності усіх елементів та напрямків діяльності з використанням персоналу банку. Таким чином, організація допомагає врегулювати усі процеси через взаємоузгоджені правила структурування. Отже, організація як функція банківського менеджменту дає змогу упорядкувати всі сторони діяльності банку (правову, технологічну, економічну, соціально-психологічну). Процес реалізації цієї функції передбачає створення взаємозв `язків та взаємовідносин, функціональних напрямків, цілей та завдань, прав та обов язків через розробку і використання відповідних положень, організаційних схем, інструкцій, документообігу, організацію внутрішніх і зовнішніх зв'язків. Таким чином функція організації полягає в формуванні іiі структури, а саме у створенні підрозділів банку та визначення їхніх повноважень, обов язків та відповідальності, формування ієрархічності.

Регулювання як функція банківського менеджменту передбачає процес прийняття та обгрунтування поточних управлінських рішень, визначення механізмів їхнього упровадження. Регулювання є базовою функцією банківського менеджменту, оскільки потреба у коригуванні планів може виникнути на будь-якій стадії управління.

Завданням банківського менеджменту $є$ мотивація усіх працівників банку для досягнення найвищих результатів діяльності. Мотивація - це діяльність, метою якої є активізація людей. Вона полягає в тому, щоб всі працівники банку виконували роботу відповідно до делегованих їм завдань і плану. Отже, це створення внутрішнього стимулу для реалізації визначеної мети.

Функція контролю банківського менеджменту передбачає перевірку виконання управлінських рішень та інформування про виявлені відхилення. Ця функція передбачає безперервність спостереження, облік, аналіз, перевірки і регулювання усіх видів діяльності банку, що зі зміною внутрішнього або зовнішнього середовища дає змогу своєчасно відкоригувати процес управління ю для досягнення визначених завдань.

Координація передбачає формування єдиного інформаційного та комунікаційного простору для чіткого розуміння визначених завдань у межах досягнення цілей банку. 
Висновки. Ефективність реалізації механізму банківського менеджменту залежить від комплексної реалізації функцій менеджменту через відповідність стратегії та оперативної діяльності; координацію відповідності стратегічних задач функціональним напрямам розвитку діяльності банку; формування зворотного зв'язку та внутрішнього та зовнішнього контролю за банківською діяльністю.

\title{
Список бібліографічного опису
}

1. В. В. Краснова, Б.О. Жнякін (2004) Фінансовий менеджмент підприємства : навч. посібник. Донецьк : Дон-НУ. 217 с.

2. Є. Г. Рясних (2010) Основи фінансового менеджменту: навч. посібник. К. : Академвидав. 336 с.

3. М. Ж. Довгань (2012) Банківський менеджмент: навч.-метод. комплекс. Тернопіль : ТНЕУ. 105 с.

4. О.А.Криклій, Н. Г. Маслак, О.М.Пожар (2011) Банківський менеджмент: питання теорії та практики : монографія. Суми : ДВНЗ “УАБС НБУ. 152 с.

5. Банківський менеджмент : Навчальний посібник (2002) О. А. Кириченко та ін. К. : Знання-Прес. 438 с.

6. І. Г. Сокиринська, Т. О. Журавльова Т.О. (2016) Фінансовий менеджмент у банку : навчальний посібник. Дніпропетровськ : Пороги. 192 с.

\section{References}

1. V. V. Krasnova, B.O. Zhniakin (2004) Finansovyi menedzhment pidpryiemstva : navch. posibnyk. Donetsk : Don-NU. 217 p. [in Ukrainian].

2. Ye. H. Riasnykh (2010) Osnovy finansovoho menedzhmentu: navch. posibnyk. K. : Akademvydav. 336 p. [in Ukrainian].

3. M. Zh. Dovhan (2012) Bankivskyi menedzhment: navch.-metod. kompleks. Ternopil : TNEU. 105 p. [in Ukrainian].

4. O. A. Kryklii, N. H. Maslak, O. M. Pozhar (2011) Bankivskyi menedzhment: pytannia teorii ta praktyky : monohrafiia. Sumy : DVNZ

"UABS NBU. 152 p. [in Ukrainian].

5. Bankivskyi menedzhment : Navchalnyi posibnyk (2002) O. A. Kyrychenko ta in. K. : Znannia-Pres. 438 p.

6. I. H. Sokyrynska, T. O. Zhuravlova T.O. (2016) Finansovyi menedzhment u banku : navchalnyi posibnyk. Dnipropetrovsk : Porohy. 192 p. [in Ukrainian].

Дата подання публікації 25.12.2020 р.

УДК 330.8:336.77(477)

Захарченко В.I., д.е.н., професор

Zakharchenko V., Doctor of Economic Sciences, Professor https://orcid.org/0000-0003-3645-2597

\section{ТЕОРЕТИЧНІ ЗАСАДИ РЕФОРМУВАННЯ КРЕДИТНОЇ СИСТЕМИ УКРАЇНИ}

\author{
Вінницький національний аграрний університет
}

\begin{abstract}
У статті показано, що для створення принципово нової за структурою і змістом кредитої системи України необхідно використати практично орієнтовані положення базових теорій кредиту натуралістичної та капіталотворчої. Відповідно, метою статті є виокремлення тих положень кредитних теорій, які в нинішніх умовах можуть скласти теоретичне підгрунтя для успішного проведення в Україні кредитої реформи.

Відмічено, що в рамках натуралістичної теорії практичне значення мають такі ії положення: класичної політичної економії - позичкового процента в контексті його впливу на динаміку інвестицій та рівень інфляції; банківської школи - доцільності «вкидання» в стагнуючу економіку додаткових інвестиційних грошей; неокласики - небезпеки відриву фінансового сектору економіки від реального та важливості зміцнення депозитної бази банків.

Наведено положення марксистської теорії кредиту, яка займає проміжне положення між натуралістичною й капіталотворчою теоріями, важливі в контексті створення в Україні повноцінного ринку цінних паперів та формування фінансово-промислових груп.

Підкреслено, що в рамках капіталотворчої теорії конструктивними є такі положення: «системи Ло»контролю центральним банком емісії кредитних грошей; теорії банківського кредиту Г. Маклеода - ролі банків в національній економіці; манчестерської школи політичної економії - переливу капіталу із менш дохідних галузей у більш дохідні; теорії економічного розвитку Й. Шумпетера - ролі кредиту у фінансування інновацій; теорії ринкової кон’юнктури М. Туган-Барановського - нагромадження фінансового капіталу на різних стадіях економічного циклу; теорії кон'юнктури Л. Гана - підтримання іï на основі кредитної експансії; теорії промислових циклів А. Пігу - розподілу капіталу між галузями на основі
\end{abstract}

